\title{
FcyRIIB mediates antigen-independent inhibition on human B lymphocytes through Btk and p38 MAPK
}

\author{
Shiang-Jong Tzeng ${ }^{*}$, Wan-Yu Li and Hui-Ying Wang
}

\begin{abstract}
Background: The inhibitory Fc receptor, FcyRIIB, has emerged as a key negative regulator of B cell activation and as such is predicted to play an essential role in controlling antibody-mediated autoimmune diseases in humans. Recent studies have shown that crosslinking the FcyRIIIB independently of the B-cell receptor (BCR) results in apoptosis in both mouse and chicken B cells. However, the human B cell subpopulations that are susceptible to BCR-independent, FcyRIIB-mediated regulation are not known. How FcyRIIB mediates this inhibition to affect $B$ cell homeostasis is also not determined.
\end{abstract}

Results: We isolated naïve B cells, memory B cells and plasma cells (PCs) from peripheral blood of healthy donors and used differentiated PCs in culture to examine the effects on them by FcyRllB crosslinking. We showed that human PCs, memory and naïve B cells all expressed FcyRIIB with expression on PCs being the highest in circulation. Moreover, they were sensitive to direct inhibition by FcyRIIIB through Btk and p38 MAPK. Similarly, PCs resulting from the antigen-independent differentiation of memory B cells in vitro were inhibited by FcyRIIB cross-linking but memory B cell activation itself, as measured by proliferation, was unaffected. In contrast, both the proliferation and differentiation of naive B cells to PCs were blocked by FcyRIIIB crosslinking.

Conclusion: These results suggest a mechanism to control antibody levels involving the differential expression of FcyRllB on B cell subpopulations, in which the FcyRIIB functions independently of the BCR to eliminate antibody-secreting effector cells and inhibit naïve B cell proliferation without compromising the long-lived antigen-specific memory B cells. Importantly, FcyRIIB requires Btk and p38 MAPK to mediate antigen-independent inhibition in human B cells. Taken together, our data underscore the importance of antigen-independent inhibition by FcyRlIB in the prevention from antibody-mediated autoimmune diseases and in the regulation of B cell homeostasis.

Keywords: FcyRIIB, Antigen, Human B cell, Btk, p38 MAPK

\section{Background}

The low affinity Fc receptor, FcyRIIB, is a potent B-cell inhibitory receptor and as such plays a central role in controlling antibody-mediated autoimmunity $[1,2]$. In humans, mutations in FcyRIIB have been associated with systemic lupus erythematosus (SLE) [3, 4], and memory $\mathrm{B}$ cells and PCs in individuals with SLE express lower levels of FcyRIIB as compared to memory B cells and PCs in healthy individuals [5], a factor that is suggested to contribute to disease [6]. The FcyRIIB exerts its

\footnotetext{
* Correspondence: sjtzeng@ntu.edu.tw

Graduate Institute of Pharmacology, College of Medicine, National Taiwan University, Room 1118, No.1, Section 1, Ren-Ai Road, Taipei 10051, Taiwan
}

inhibitory effect on B cells via what appears to be two distinct signaling pathways. When coligated to the B-cell receptor (BCR) through the binding of antigen-containing immune complexes (ICs), the FcyRIIB inhibits antigenspecific antibody responses by blocking BCR signaling. Such inhibition involves the phosphorylation of the immunoregulatory tyrosine inhibitory motif (ITIM) in the cytoplasmic domain of the FcyRIIB by Lyn, and the recruitment of the lipid phosphatase, SHIP [7-9]. In contrast, recent evidence indicates that when clustered independently of the BCR, the FcyRIIB initiates an ITIM-, Lyn- and SHIP-independent pathway that triggers apoptosis through a mechanism that involves c-Abl family kinases $[10,11]$. Thus, the FcyRIIB has the ability to block 
both the BCR-dependent, antigen-driven activation of $\mathrm{B}$ cells as well as antigen-independent, BCR-independent B cell activation. There is considerable evidence that the BCR-dependent Fc $\gamma$ RIIB inhibitory pathway plays an important role in regulating the antigen-driven activation of naïve $B$ cells to proliferate and differentiate to PCs [12]. However, the $B$ cell subpopulations that are susceptible to BCR-independent, FcyRIIB-mediated inhibition are not as clearly delineated. It was recently shown, in mice, that long-lived bone marrow PCs express the FcyRIIB and that engaging the FcyRIIB by ICs induces these bone marrow PCs to undergo antigen-independent apoptosis [13]. In addition, Rahman et al. [14] provided evidence, in mice, that the Fc $\gamma$ RIIB regulates PCs but not germinal center B cells. Thus, in mice, the accumulation and persistence of PCs in the bone marrow appears to be regulated by ICs through the inhibitory FcyRIIB independently of the BCR. At present, the effect of FcyRIIB crosslinking on the antigen-independent activation of human B cell subpopulations is not known.

Here we investigate the ability of the BCR-independent Fc $\gamma$ RIIB inhibitory pathway to directly inhibit human peripheral blood PCs and to block the antigen-independent activation of human naïve and memory B cells to proliferate and differentiate into PCs in vitro. We provide evidence that the FcyRIIB is most highly expressed on PCs and that IgG-secreting cells from human peripheral blood are sensitive to direct inhibition by Fc $\gamma$ RIIB-crosslinking. Crosslinking the FcyRIIB also inhibits PCs resulting from the antigen-independent differentiation of human memory $B$ cells but has no direct effect on the antigenindependent activation of memory B cells to proliferate. Lastly, we show that both the antigen-independent proliferation and differentiation of naïve $B$ cells in vitro are blocked by Fc $\gamma$ RIIB crosslinking. Taken together, these results suggest that the BCR-independent Fc $\gamma$ RIIB signaling pathway may play an important role in humans in acutely controlling antibody levels by inhibiting antibodysecreting PCs and the activation of naïve $B$ cells without affecting the long-lived memory B-cell pool, which is capable to quickly expand and differentiate into PCs to provide protective humoral immunity upon reencountering antigen.

\section{Methods}

\section{Antibodies and reagents}

The FcyRIIB-specific mAb AT10 (biotinylated, FITCand PE-conjugated) was obtained from Abcam (Cambridge, MA, USA) [15]. Goat IgG and rabbit anti-goat IgG were used to make ICs as previously described [11]. Mouse IgG1, rabbit peroxidase-anti-peroxidase (PAP) ICs were purchased from Jackson ImmunoResearch Laboratories (West Grove, PA, USA). CpG 2006 was purchased from Santa Cruz Biotechnology (Dallas, TX,
USA). Mouse isotype control mAbs and mAbs specific for CD19 (SJ25C1), CD45 (HI30), CD27 (L128), CD38 (HB7) and CD14 (M5E2) were purchased from BD Biosciences (San Jose, CA, USA). Recombinant human IL21, IL-2 and IL-10 and human SCD40L were purchased from PeproTech (Rocky Hill, NJ, USA). Antibodies specific for CD27 (O324), CD19 (HIB19) and CD20 (2H7) were purchased from eBioscience (San Diego, CA, USA). Human B cell isolation kit was obtained from BD Biosciences. Staphylococcus aureus Cowan (SAC) and lectin from Phytolacca Americana (Pokeweed mitogen, PWM) were obtained from Merck Millipore (Billerica, MA, USA) and Sigma-Aldrich (St. Louis, MO, USA), respectively. Carboxyfluorescein succinimidyl ester (CFSE) was acquired from eBioscience (San Diego, CA, USA). SB203580, SP600125, Z-VAD-FMK, LFM-A13 and ibrutinib (PCI32765) were all purchased from Selleck Chemicals (Houston, TX, USA).

\section{Isolation and culture of human peripheral blood B cells}

Human peripheral blood was obtained from healthy donors with informed consent and the use of it was conformed to the approved guidelines established by the Institutional Review Board of National Taiwan University Hospital (reference numbers: 201005012R and 201307019RINB). Erythrocytes in human peripheral blood cells were first depleted by lysis buffer $(150 \mathrm{mM}$ $\mathrm{NH}_{4} \mathrm{Cl}, 10 \mathrm{mM} \mathrm{KHCO} 3,1 \mathrm{mM}$ EDTA, pH 7.4). After centrifugation the pellets were layered over a FicollPaque Plus (GE Healthcare, Uppsala, Sweden) gradient (2,000 rpm, $20 \mathrm{~min})$ to collect lymphocytes at the gradient interface. For flow cytometric analysis cells were further layered over a fetal calf serum gradient to remove platelets $(800 \mathrm{rpm}, 15 \mathrm{~min})$ to decrease nonspecific binding to mAbs. The cell pellet was washed, resuspended and cultured on plastic cell-culture dishes for 30-60 min to remove adherent cells. Nonadherent cells were harvested and resuspended in PBS $(0.5 \% \mathrm{BSA})$ and B cells were purified by negative selection using the human B cell isolation kit (Merck Millipore) according to the manufacturer's protocol. Biotinylated mouse mAbs specific for CD3 and CD16 (BD Biosciences) were added to the cocktail mAbs to increase the efficiency of depleting non-B cells. The resulting B cell populations were $95-98 \%$ pure as assessed by CD19 and/or CD20 expression. Purified B cells were further separated into $\mathrm{CD} 27^{+}$memory and CD27 $7^{-}$naïve subsets using CD27 mAb-conjugated microbeads (Miltenyi Biotec). Alternatively naïve and memory B cells were obtained by cell sorting gating on $\mathrm{CD} 19^{+}$cells and then sorting into $\mathrm{CD} 27^{+}$and $\mathrm{CD} 27^{-}$ populations using FACSAria cell-sorting system (BD Biosciences). Likewise, PCs were sorted as $\mathrm{CD} 19^{+} \mathrm{CD} 27^{+} \mathrm{CD} 38^{+}$. The experimental results from $\mathrm{B}$ cells fractionated by $\mathrm{mAb}-$ 
conjugated beads or by sorting were comparable. Purified cell populations $\left(5-10 \times 10^{5} / \mathrm{ml}\right)$ were cultured in RPMI1640 medium (Thermo Scientific) supplemented with $10 \%$ heat-inactivated fetal calf serum, $2 \mathrm{mM}$ L-glutamine, 100 $\mathrm{U} / \mathrm{ml}$ penicillin, $100 \mathrm{mg} / \mathrm{ml}$ streptomycin and $50 \mu \mathrm{M} \beta$ mercaptoethanol. CpG was added at the concentration of $5 \mu \mathrm{g} / 10^{6}$ cells $/ \mathrm{ml}$. SAC (at a $1: 10,000$ dilution), PWM (at a 1:100,000 dilution), recombinant human IL-2 (10 ng/ml), IL-10 (10 ng/ml), IL-21 (100 ng/ml) and sCD40L (1 $\mu \mathrm{g} / \mathrm{ml})$ were added accordingly [16-22].

\section{Flow cytometry}

To detect FcyRIIB surface expression, cells were incubated with AT10-FITC. The percentage of dead cells was measured by 7-aminoactinomycin D (7-AAD). Multi-color flow cytometry was performed using Fortessa (BD Biosciences) and analyzed using Flowjo v7.6 (Tristar).

\section{Proliferation and cell division assays}

Purified B cells $\left(10^{6} / \mathrm{ml}\right)$ were stimulated in triplicates in 96-well plates in the presence of an isotype control $\mathrm{mAb}$ or AT10 mAb $(5 \mu \mathrm{g} / \mathrm{ml})$ for $48-72 \mathrm{~h}$ before adding $\left[{ }^{3} \mathrm{H}\right]$ methyl thymidine $(1 \mu \mathrm{Ci} /$ well $)$ for an additional $16 \mathrm{~h}$. Cells were harvested and transferred onto a 96-well filter paper (PerkinElmer-Wallac, Waltham, MA, USA) and the radioactivity associated with the filter papers was determined using a $\beta$ counter. CFSE labeling to detect dividing cells was performed following the manufacturer's protocol (eBioscience).

\section{ELISPOT assay}

Ninety six-well MultiScreen HTS filter plates (Merck Millipore) were coated with $\mathrm{F}\left(\mathrm{ab}^{\prime}\right)_{2}$ goat antibodies specific for human IgG + IgM antibodies $(5 \mu \mathrm{g} / \mathrm{ml})$ in PBS at $4{ }^{\circ} \mathrm{C}$ overnight. After washing with PBS and blocking with culture medium, $100 \mu \mathrm{l}$ fresh medium was added to each well before adding cells (2-fold serial diluted) for culture at $37{ }^{\circ} \mathrm{C}$ for $4-6 \mathrm{~h}$. Plates were washed with PBS $(0.1 \%$ Tween 20$)$ and then incubated in $100 \mu \mathrm{l} /$ well PBS $\left(0.5 \%\right.$ BSA) with biotinylated $\mathrm{F}\left(\mathrm{ab}^{\prime}\right)_{2}$ goat antibodies specific for human $\mu$ chain or $\gamma$ chain (1:5000, Jackson ImmunoResearch Laboratories) at $4{ }^{\circ} \mathrm{C}$ overnight. After washing, alkaline phosphatase-conjugated streptavidin (Merck Millipore) was added (100 $\mu \mathrm{l} /$ well) and incubated at ambient temperature for $2-4 \mathrm{~h}$ and the plates were developed using ACE kit (Merck Millipore). After drying, the plates were scanned and analyzed using C.T.L. ImmunoSpot scanner and software (version 4).

\section{Statistical analyses}

Graphs and histograms were plotted using GraphPad Prism 5 (San Diego, CA, USA). Statistical analysis was performed using one-way ANOVA (repeated measures for paired values) and Turkey's multiple comparison tests.

\section{Results}

The expression of FcyRIIB on peripheral blood PCs, memory and naive $B$ cells

To determine the populations of human peripheral B cells that are potential targets of FcyRIIB-mediated inhibition, we determined the expression of Fc $\gamma$ RIIB on naïve $\mathrm{B}$ cells $\left(\mathrm{CD} 19^{+} \mathrm{CD} 27^{-} \mathrm{CD} 38^{-}\right)$, memory $\mathrm{B}$ cells $\left(\mathrm{CD} 19^{+} \mathrm{CD} 27^{+} \mathrm{CD} 38^{-}\right)$and $\mathrm{PCs}\left(\mathrm{CD} 19^{+} \mathrm{CD} 27^{+} \mathrm{CD} 38^{+}\right)$ by flow cytometry (Fig. 1). The three subpopulations showed a hierarchical order of FcyRIIB expression with PCs $>$ memory B cells $>$ naïve B cells (Fig. 1a, b). This pattern held in the vast majority of cases when the expression of FcyRIIB was compared between the B cell populations within each individual donor (Fig. 1c). These findings suggest that each of these human B cell populations is potentially susceptible to FcyRIIB regulation and that the outcome of FcyRIIB-crosslinking may differ between the populations, either quantitatively or qualitatively, as a consequence of the differences in the levels of Fc $\gamma$ RIIB expression.

\section{FcyRIIB crosslinking inhibits viability of $\mathrm{CD} 19^{+} \mathrm{CD} 27^{+} \mathrm{CD} 38^{+}$ $\mathrm{PCs}$ and in vitro differentiation of PCs}

To determine the direct effect of FcyRIIB crosslinking on ASCs, $\mathrm{CD} 19^{+} \mathrm{CD} 27^{+} \mathrm{CD} 38^{+} \mathrm{PCs}$ were isolated from human peripheral blood cells as described in Material and Methods. Taken directly from the peripheral blood the purified PCs gradually became quiescent and 30\% of them underwent spontaneous apoptosis in culture medium after $24 \mathrm{~h}$. Nevertheless, incubation of these PCs for $24 \mathrm{~h}$ with the presence of FcyRIIB-specific mAbs AT10, or ICs to crosslink the FcyRIIB resulted in a significant reduction of $\sim 15-20 \%$ in cell viability (Fig. 2a). This circulating population of PCs appeared to contain mostly IgG-ASCs in a frequency of $\sim 50-100$ per $10^{4}$ $\mathrm{CD} 19^{+}$cells, and many fewer IgM-ASCs $\left(0-50\right.$ per $\left.10^{4}\right)$. Crosslinking the FcyRIIB also significantly reduced the number of both IgM- and IgG-ASCs (Fig. 2b). Shown were the percent of viable cells and the numbers of IgGand IgM-secreting cells $24 \mathrm{~h}$ after treatment with AT10 $\mathrm{mAb}$ for six different individuals. Thus, regardless of their BCR specificities the ASCs from peripheral blood are sensitive to direct inhibition by Fc $\gamma$ RIIB crosslinking. Since no exogenous growth factors or cytokines were added into the medium, this inhibitory effect can be attributed to an increase in apoptosis rather than a block in proliferation as there was no appreciable change in cell number in either control or treated cultures (Fig. 2a). Consistently, the doubling time of human primary B cells in culture was reported to be $\sim 36 \mathrm{~h}$ [23], which was 

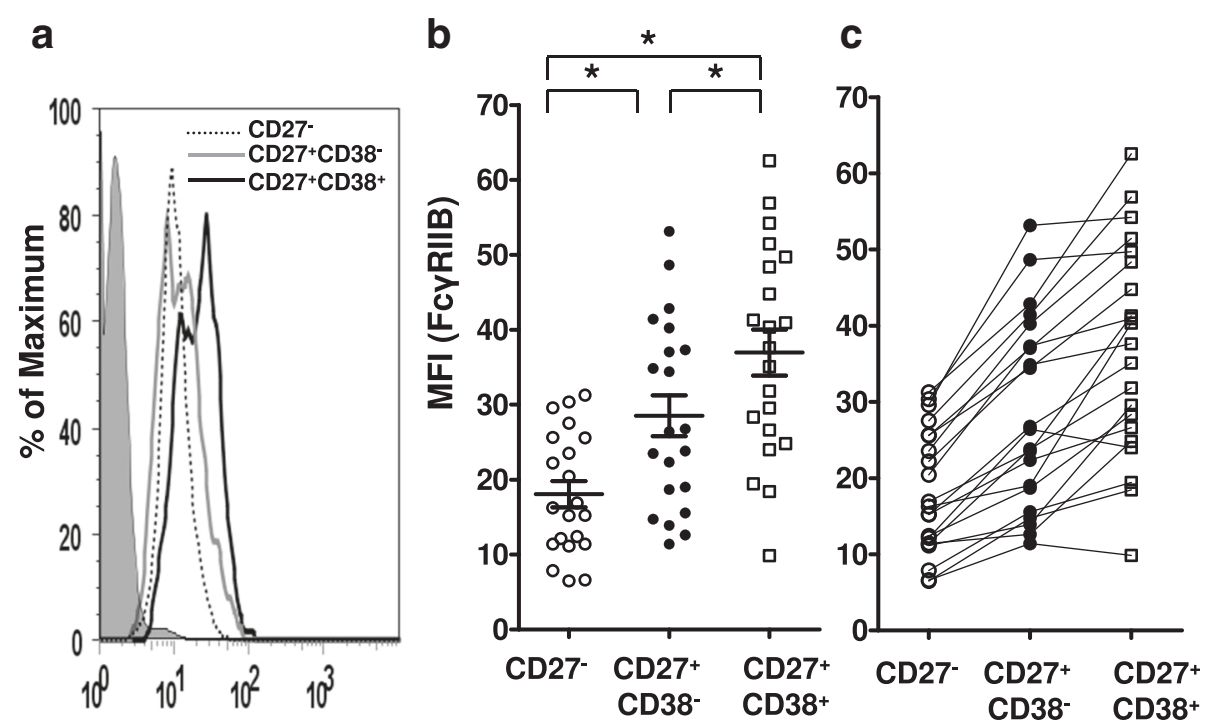

Fig. 1 Human memory B cells, naive B cells and PCs express FcyRllB. a B cells were first gated by $C D 45^{+} C D 19^{+}$and further gated to $C D 27^{-}, C D 27^{+} C D 38$ and $C D 27^{+} \mathrm{CD} 38^{+}$subsets for their expression levels of FcyRIIB . A representative histogram of the mean fluorescence intensity (MFI) of one donor is shown. $\mathbf{b}$ A scatter dot plot (mean \pm SEM) of the expression levels of FcyRIIB of the three subpopultions of B cells from 21 donors is shown. The asterisks indicated that the comparisons are statistically significant $(P<0.01)$. $\mathbf{c}$ The FCyRllB expression levels of memory B cells, naive B cells and PCs for individual donors are shown

longer than the period of $24 \mathrm{~h}$ to observe the effect of AT10 mAb (Fig. 2a and b).

We also examined the effect of Fc $\gamma$ RIIB crosslinking on the differentiation of ASCs from B cells in vitro. Recent evidence indicated that human peripheral blood B cells express Toll-like receptor 9 (TLR9) and are responsive to TLR9 agonist, CpG ODN, to differentiate into $\mathrm{CD} 19^{+} \mathrm{CD} 27^{+} \mathrm{CD} 38^{+} \mathrm{PCs}$ in 3 to 5 days in vitro $[23,24]$. Consistent with previous findings, we observed that most ( $80-90 \%)$ mature circulating antibody-secreting PCs died during the first $48 \mathrm{~h}$ of culture [23, 24]. Newly differentiated IgM- and IgG-secreting PCs appeared by day three in culture at a frequency of approximately 50 PCs per $10^{4} \mathrm{CD} 19^{+}$cells (Fig. 2c) and by day five in culture the number of IgG-antibody secreting PCs increased to approximately 100 per $10^{4} \mathrm{CD} 19^{+}$cells (Fig. 2c). The presence of the AT10 mAb or ICs significantly reduced the number of both IgM- and IgG-ASCs that resulted from $\mathrm{CpG}$ stimulation of PCs measured after 3 days in culture (Fig. 2c). The addition of IL-2 and IL-10 or SAC and PWM that are stronger inducers to $\mathrm{BCR}$ to the $\mathrm{CpG}$-containing cultures increased the resulting number of both IgM- and IgG-ASCs [16] and in both cases the number of ASCs was reduced significantly by the presence of the AT10 mAb but not by an isotype matched control mAb (Fig. 2c). Taken together these results indicate that the human ASCs either isolated directly from human peripheral blood or resulting from the differentiation of PCs in vitro are sensitive to inhibition by Fc $\gamma$ RIIB crosslinking independent of BCR.
The effect of FcyRIIB crosslinking on the antigenindependent differentiation of $B$ cells to PCs

Human B cells have been shown to respond to the TLR9 agonist, $\mathrm{CpG}$, by proliferating and differentiating into antibody secreting PCs. Bernasconi et al. $[17,18]$ reported that $\mathrm{CpG}$ single agent activated IgM memory B cells $\left(\mathrm{CD} 19^{+} \mathrm{CD} 27^{+} \mathrm{IgG}^{-}\right)$and switched memory B cells $\left(\mathrm{CD} 19^{+} \mathrm{CD} 27^{+} \mathrm{IgD}^{-} \mathrm{IgM}^{-}\right)$to proliferate and differentiate into antibody secreting PCs, but had little effect on naïve $\mathrm{B}$ cells $\left(\mathrm{CD} 19^{+} \mathrm{CD} 27^{-}\right)$. We determined the effect of crosslinking the FcyRIIB on the differentiation of purified $\mathrm{CD} 19^{+}$peripheral blood B cells to PCs in response to $\mathrm{CpG}$, using the ICs. The highly purified $\mathrm{CD} 19^{+}$peripheral blood B-cell population contained less than $0.5 \% \mathrm{CD}^{2} 8^{+}$PCs by flow cytometry (Fig. 3) and no ASCs by ELISPOT analyses after 3 days in culture (data not shown). Culturing these purified $\mathrm{B}$ cells with $\mathrm{CpG}$ induced the differentiation to $\mathrm{CD} 19^{+} \mathrm{CD} 27^{+} \mathrm{CD} 38^{+} \mathrm{PCs}$ over a 5-day culture as measured by flow cytometry (Fig. 3). In the absence of CpG no PCs were detected in the 5-day cultures (data not shown). In the presence of $\mathrm{CpG}, 7.9$ to $8.1 \%$ of the cells recovered from the 5 day cultures were $\mathrm{PCs}$ and this number was significantly decreased to 3.5 to $4.2 \%$ by the presence of the AT10 mAb or ICs in the 5-day cultures. An isotype matched control $\mathrm{mAb}$ had no effect on the CpG-induced generation of PCs. Consistently, in the presence of $\mathrm{CpG}$ the reduced number of $\mathrm{PCs}$ by AT10 mAb or ICs appeared to correlate to the decrease of ASCs (Fig. 2c and Fig. 3). 

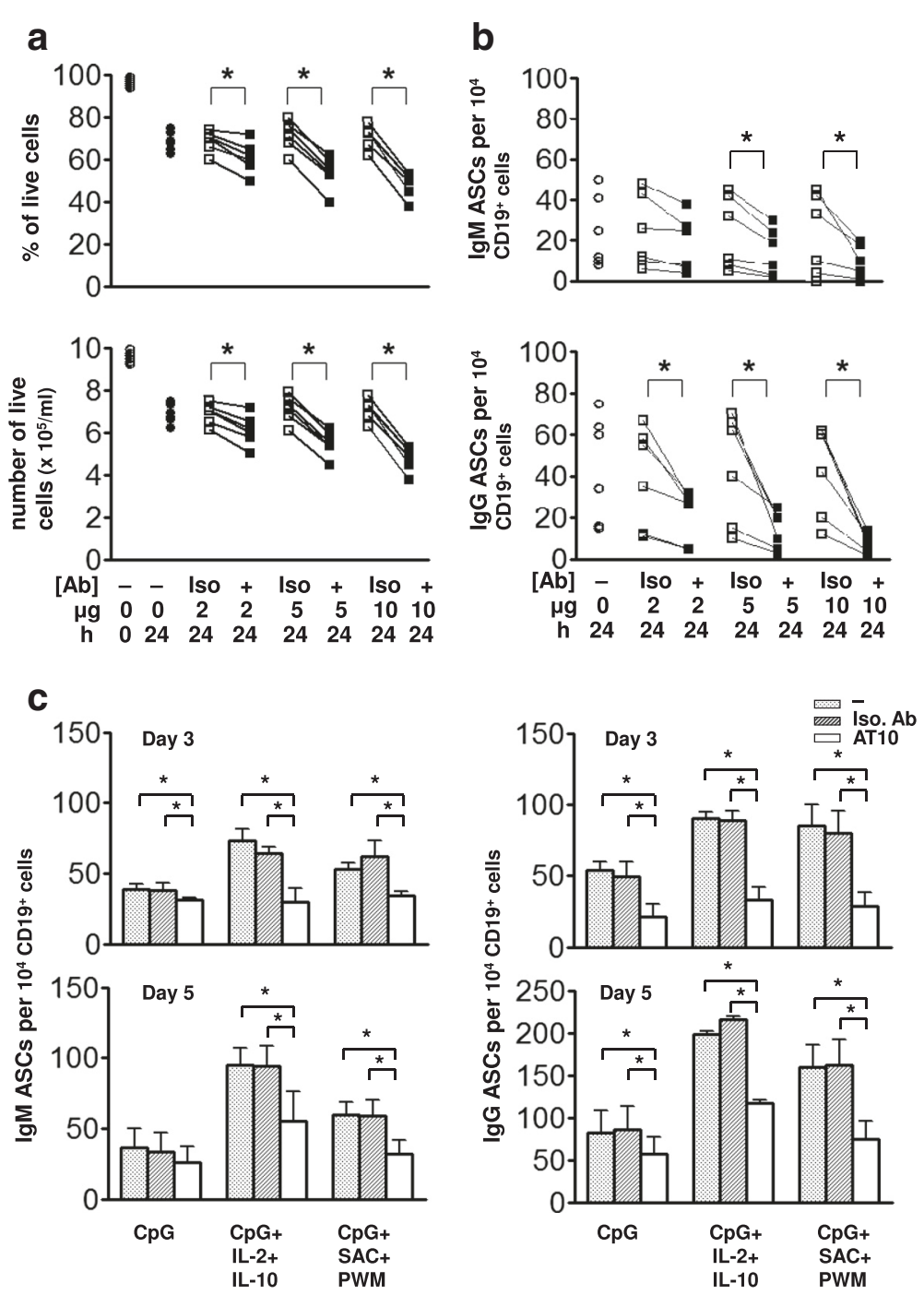

Fig. 2 Crosslinking FCYRIIIB inhibits cell viability of purified primary PCs and subsequent PC differentiation in vitro. a Purified PCs $\left(10^{6} / \mathrm{ml}\right)$ were cultured for $24 \mathrm{~h}$ in the absence (circle) or presence of various doses $(2-10 \mu \mathrm{g} / \mathrm{ml}$ ) of isotype (squares) or AT10 (filled squares) mAbs. The number and percentage of dead cells were determined by staining with 7-AAD and side scattering using flow cytometry. $\mathbf{b}$ Primarily isolated CD19+ $B$ cells $(10 \% \mathrm{ml})$ were cultured for $24 \mathrm{~h}$ as in (a) in 96-well ELISPOT plates as described in Methods. c Purified B cells from 6 donors were cultured as in (b) with the addition of $\mathrm{CpG}(5 \mu \mathrm{g} / \mathrm{ml})$ alone, $C p G+I L-2+I L-10$ or $C p G+S A C+P W M$ for three or five days without antibody or in the presence of an isotype matched control mAb or AT10 mAb $(5 \mu \mathrm{g} / \mathrm{ml})$. The asterisks indicate that the differences between the groups compared are statistically significant $(P<0.05)$

The effect of crosslinking the FcyRIIB on the differentiation of $\mathrm{CD} 19^{+} \mathrm{B}$ cells in response to $\mathrm{CpG}$ was also determined by an ELISPOT assay, capturing antibodies secreted by PCs using either IgM- or IgG-specific antibodies. CpG induced the differentiation of both IgM- and IgG-secreting PCs, suggesting that both IgM memory B cells and switched memory B cells were activated to differentiate to PCs. In the absence of CpG few viable cells and no antibody secreting PCs were recovered from the 5-day cultures (data not shown). The addition of the AT10 mAb reduced the numbers of both IgG- and IgM-secreting PCs in cultures in a dosedependent fashion as compared to an isotype matched nonspecific control mAb (Fig. 4). The average of the results from $B$ cells purified from several individual donors showed that crosslinking the FcyRIIB resulted in a significant decrease in the number of IgM- and IgG-secreting PCs (Fig. 4, top). An analysis of each individual donor showed a large individual to individual variation in the number of $\mathrm{PCs}$ that resulted from $\mathrm{CpG}$ stimulation of B cells but for each individual crosslinking the FcyRIIB reduced that number significantly 


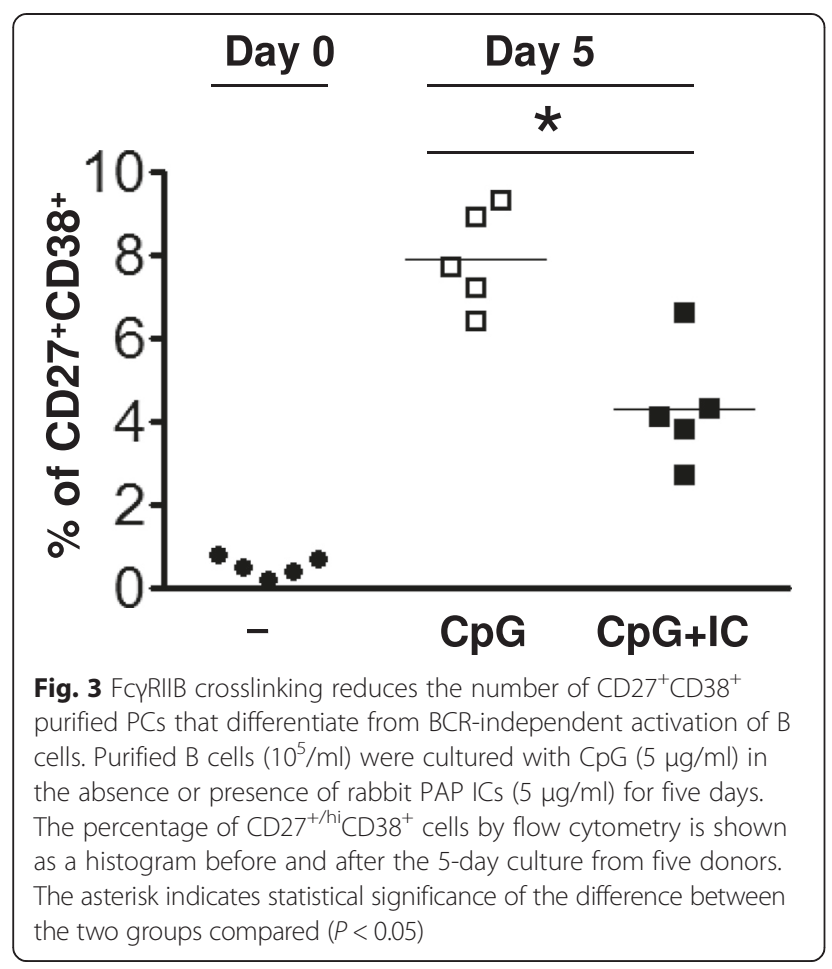

(Fig. 4, bottom). FcyRIIB crosslinking did not have a significant effect on the overall cell numbers or cell viability in culture (data not shown), suggesting that the effect of FcyRIIB crosslinking may be at the level of the relatively small population of newly generated PCs.
FcyRIIB crosslinking reduces the number of PCs resulting from the differentiation of both naïve and memory $B$ cells The effect of FcyRIIB crosslinking on the antigenindependent, CpG-induced differentiation of memory B cells and naïve $\mathrm{B}$ cells to PCs was tested. To do so, purified peripheral blood $\mathrm{CD} 19^{+} \mathrm{CD} 38^{-} \mathrm{B}$ cells were separated into $\mathrm{CD} 27^{+}$memory and $\mathrm{CD} 27^{-}$naïve $\mathrm{B}$ cell. Memory and naïve $B$ cells were incubated with $\mathrm{CpG}$ in the presence of graded concentrations of either AT10 $\mathrm{mAb}$ or an isotype matched control mAb (Fig. 5). CpG alone induced the differentiation of both IgG- and IgMsecreting PCs from memory B cells from the nine individual donors analyzed and the number of PCs was reduced by AT10 mAb in a dose dependent fashion but not by the isotype matched control mAb. The AT10 $\mathrm{mAb}$ was effective in reducing the number of IgM- and IgG-secreting PCs at $5 \mu \mathrm{g} / \mathrm{ml}$. Naïve B cells were only weakly responsive to $\mathrm{CpG}$ as described previously by Bernasconi et al. [17, 18] and Jiang et al. [19] and most of the resulting PCs secreted IgM (Fig. 5). The number of IgM-secreting PCs was reduced by the AT10 mAb with the largest decrease observed at $10 \mu \mathrm{g}$ of AT10.

We also tested the ability of the FcyRIIB to reduce the number of PCs resulting from the response of $\mathrm{B}$ cells to combinations of $\mathrm{CpG}$ and other mitogens, cytokines and $\mathrm{BCR}$ agonists that have been reported to influence the response of naïve and memory B cells to CpG (Fig. 6). Consistent with previously reported by Jiang et al. [19], CpG alone induced naïve B cells into more IgM-ASCs than IgG-ASCs in a 5-day culture (Fig. 6). Bernasconi
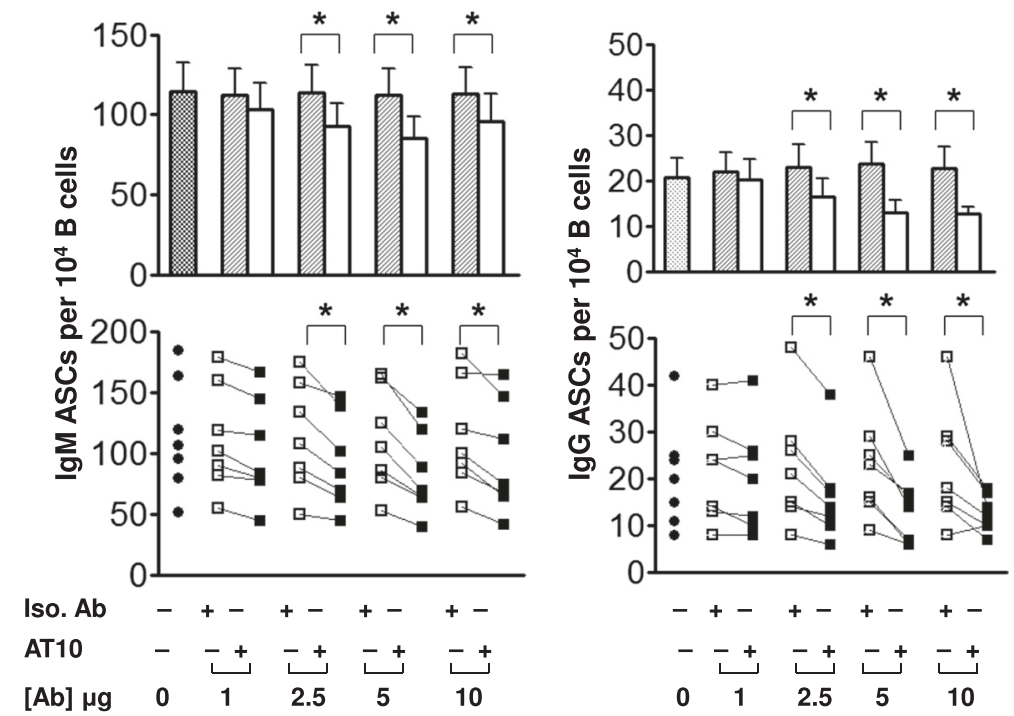

Fig. 4 FcyRIIB crosslinking reduces the number of antibody-secreting PCs resulting from BCR-independent activation of B cells. Purified B cells were treated with CpG $(5 \mu \mathrm{g} / \mathrm{ml})$ without additional antibody or in the presence of an isotype matched control mAb or AT10 mAb in graded concentrations $(0,1,2.5,5$ or $10 \mu \mathrm{g} / \mathrm{ml})$ for five days. ELISPOT analyses were performed to measure total lgM- and lgG-antibody-secreting PCs. Data are shown as an average of all individuals analyzed (top) or for individual donors (bottom). The asterisks indicate that the differences between the groups compared are statistically significant $(P<0.05)$ 


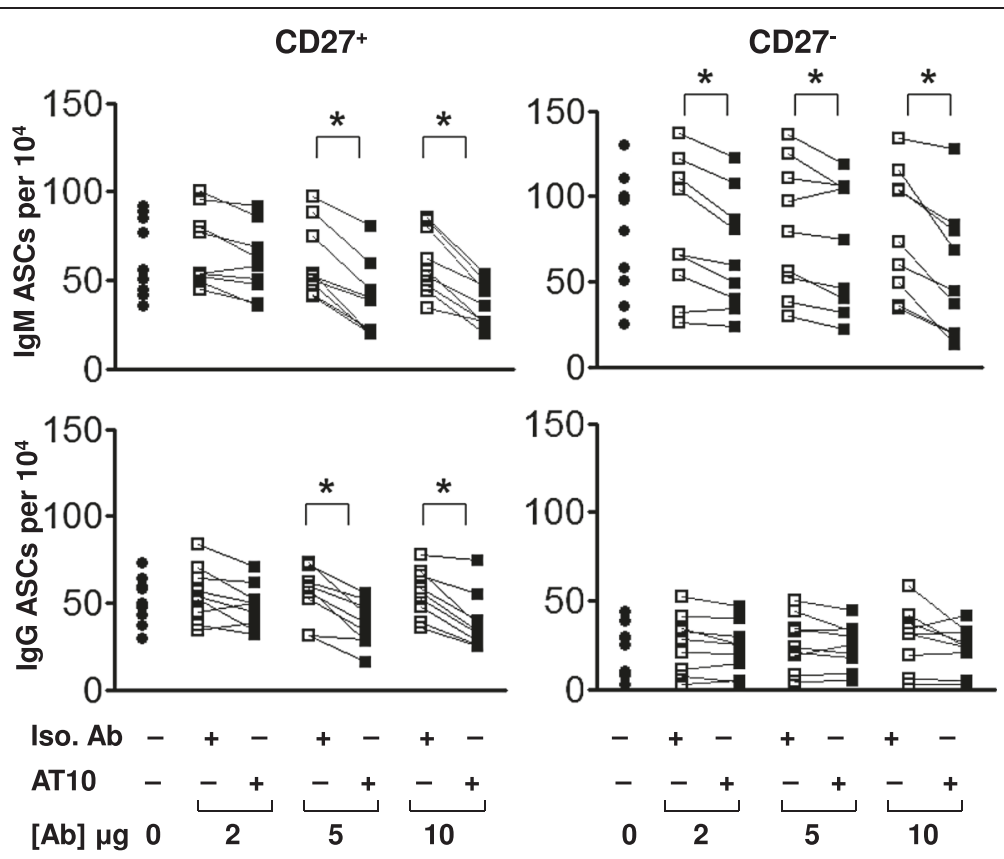

Fig. 5 FCYRIIB crosslinking reduces the number PCs resulting from the BCR-independent differentiation of $C D 27^{+}$memory and $C D 27^{-}$naïve $B$ cells. CD27 $7^{+}$and $C D 27^{-}$B cells from eight donors were treated with $\mathrm{CpG}$ as in Fig. 4 at various concentrations of isotype matched control or AT10 mAbs $(0,2,5$, or $10 \mu \mathrm{g} / \mathrm{ml})$ for five days. The number of IgM- and lgG-antibody-secreting PCs was determined by ELISPOT assay. The asterisks indicate that the differences between the groups compared are statistically significant $(P<0.05)$
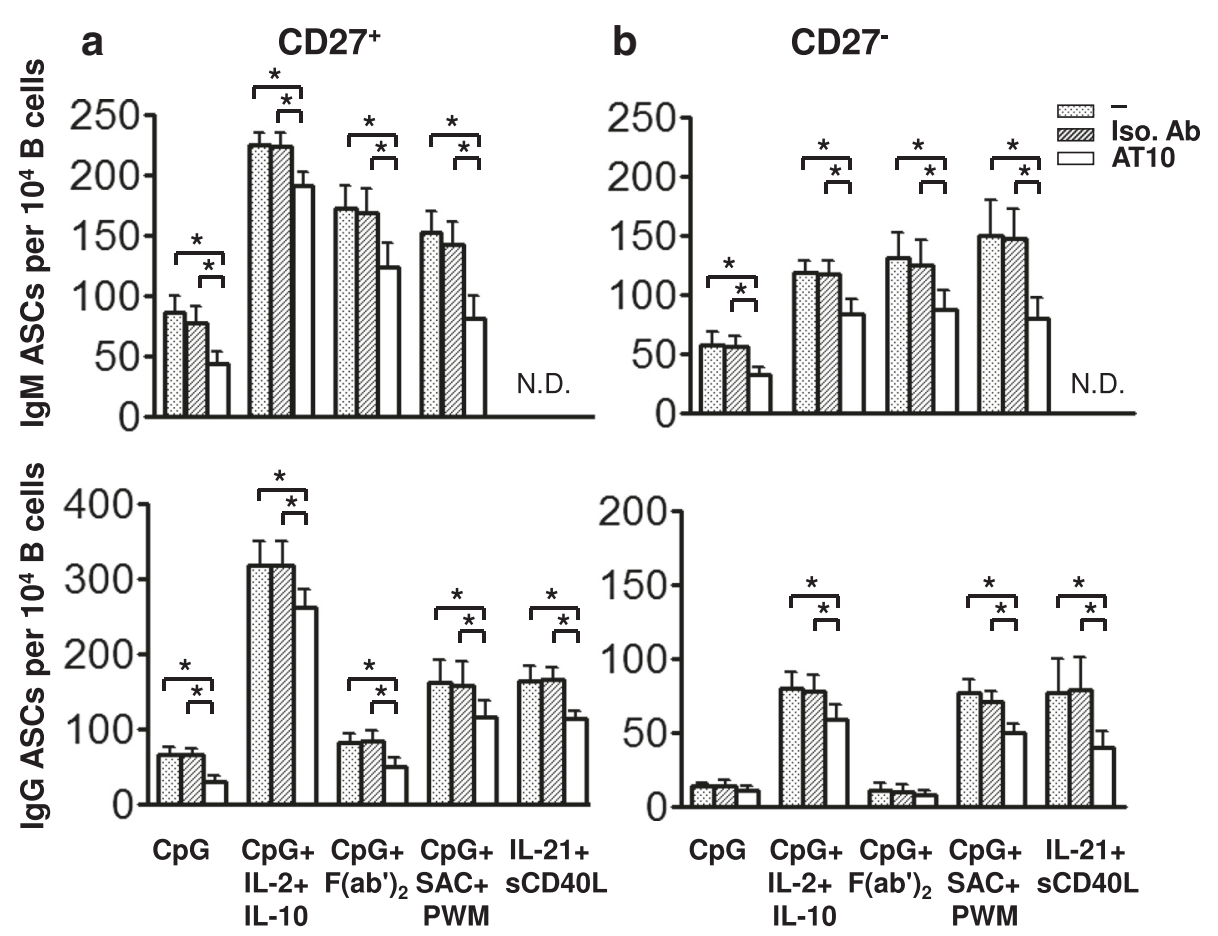

Fig. 6 FcyRIIB crosslinking reduces the number of PCs that result from the differentiation from $C D 27^{+}$memory and from $C D 27^{-}$naïve $B$ cells to a variety of stimuli. a CD27 memory $B$ cells or $\mathbf{b} C D 27^{-}$naïve $B$ cells were incubated without additional antibody or in the presence of an isotype matched control mAb or AT10 mAb $(5 \mu \mathrm{g} / \mathrm{ml})$ and either CpG $(5 \mu \mathrm{g} / \mathrm{ml})$ alone, CpG + IL-2 + IL-10, CpG + F (ab') $)_{2}$ fragment of anti-lg, CpG + SAC + PWM or IL-21 + SCD40L. The number of IgM- and IgG-antibody-secreting PCs was determined by ELISPOT assay. The asterisks indicate that the differences between the groups compared are statistically significant $(P<0.05)$ 
et al. showed that the addition of the cytokines IL-2 and IL-10 to the CpG-containing cultures increased the numbers of PCs produced from memory B cells and also resulted in a limited differentiation of naïve $B$ cells $[18,20]$. The addition of IL-2 and IL-10 to CpG-containing cultures significantly increased the number of both IgM- and IgGsecreting PCs and this number was reduced by the AT10 $\mathrm{mAb}$. We also tested the effect of $\mathrm{F}\left(\mathrm{ab}^{\prime}\right)_{2}$ anti-Ig in combination with $\mathrm{CpG}$ on the differentiation of memory B cells as Bernasconi et al. had shown that BCR crosslinking influenced the response of IgM memory and naïve cells to $\mathrm{CpG}$ [18]. Incubating memory $\mathrm{B}$ cells with $\mathrm{CpG}$ and $\mathrm{F}\left(\mathrm{ab}^{\prime}\right)_{2}$ anti-Ig resulted in an increase in the IgM-secreting PCs as compared to CpG alone but had no effect on the IgGsecreting PCs, suggesting that crosslinking the BCR only affected the activation of IgM memory B cells. Crosslinking the Fc $\gamma$ RIIB decreased the number of PCs under these conditions. Crotty et al. [21] showed that a combination of $\mathrm{CpG}$ and S. aureus Cowan (SAC) and Pokeweed mitogen (PWM) activated memory B cells $\left(\mathrm{CD} 19^{+} \mathrm{CD} 27^{+}\right)$to differentiate to IgG secreting PCs. Culturing memory B cells with CpG in combination with SAC and PWM induced an increase in both IgM- and IgG-producing PCs over CpG alone and the AT10 mAb decreased the number of PCs in each case. Lastly, a combination of IL-21 and SCD40L induced memory B cell differentiation exclusively to IgGsecreting PCs [22] and the number of IgG-secreting PCs was blocked by Fc $\gamma$ RIIB crosslinking. These findings indicate that the antigen-independent activation of memory $\mathrm{B}$ cells to differentiate to PCs by a variety of different stimuli is inhibited by FcyRIIB crosslinking. Given that PCs are themselves inhibited by FcyRIIB crosslinking, the simplest interpretation of these results is that the Fc $\gamma$ RIIB acts to inhibit the newly generated PCs rather than blocking the activation of the memory $B$ cells themselves.

Naïve B cells differentiated primarily into IgM-secreting PCs in response to all stimuli tested [18] with the exception of IL-21 and SCD40L that promotes isotype switching [22] and in each case the number of PCs was decreased in the presence of AT10 mAb but not an isotype matched control mAb (Fig. 6). The effect of AT10 mAb was also tested on PCs differentiated by IL-21 in combination with sCD40L, conditions that induced isotype switching in B cells [22]. These culture conditions yielded exclusively IgG-secreting PCs and these IgG-ASCs were reduced by the AT10 mAb but not the isotype matched control mAb. These results suggest that the PCs differentiating from naïve B cells are inhibited by FcyRIIB crosslinking.

\section{FcyRIIB crosslinking triggers apoptosis of human B cells through Btk and p38 MAPK}

We next investigated the molecular mechanism for the antigen-independent apoptosis induced by FcyRIIB. Since Pearse et al. reported that Fc $\gamma$ RIIB crosslinking triggers apoptosis through Btk and JNK in chicken DT40 B cells [10], we first examined this possibility with two selective Btk inhibitors, LFM-A13 and ibrutinib, both of which significantly blocked apoptosis induced by ICs to a similar degree compared to controls. The reversal of FcyRIIBmediated inhibition was most apparent in PCs (Fig. 7a). This is consistent with the fact that PCs have the highest expression level of Fc $\gamma$ RIIB, thereby conferring the highest induction of apoptosis among circulating B cells (Figs. 1 and 2). To further investigate the signaling intermediaries downstream of Btk, we treated naïve, memory B cells and PCs with either SP600125, a JNK inhibitor or SB203580, a p38 MAPK inhibitor in the presence of ICs for $24 \mathrm{~h}$. Unlike previously reported in DT40 chicken B cells [10], the p38 MAPK, but not JNK was involved in Fc $\gamma$ RIIBmediated apoptosis in human B cells (Fig. 7b).

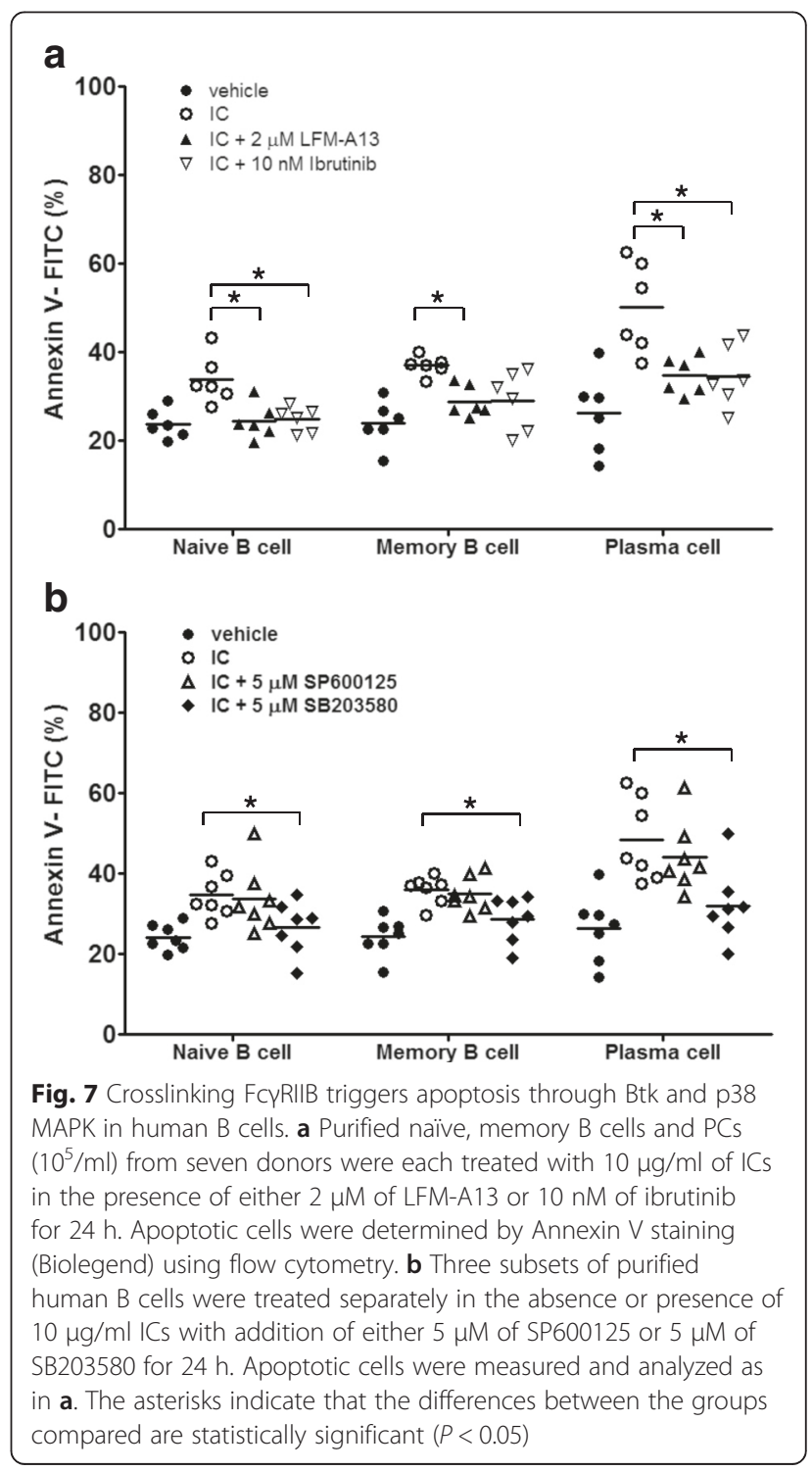




\section{The effect of crosslinking the FcyRIIB on naïve and memory B cell proliferation}

We tested the effects of crosslinking the FcyRIIB on the proliferative responses of $\mathrm{CD} 19^{+} \mathrm{CD} 27^{+} \mathrm{CD} 38^{-}$memory $\mathrm{B}$ cells and $\mathrm{CD} 19^{+} \mathrm{CD} 27^{-} \mathrm{CD} 38^{-}$naive $\mathrm{B}$ cells to the same combinations of CpG, cytokines and BCR agonists assessed above in Fig. 6. Memory B cells proliferated over a 2-day period to $\mathrm{CpG}$ in combination with IL-2 plus IL-10, F (ab') $)_{2}$ anti-Ig or SAC plus PWM (Fig. 8a). The response in each case was refractory to the effects of the AT10 mAb even at high antibody concentrations (10 $\mu \mathrm{g} / \mathrm{ml})$ (data not shown). Moreover, in the presence of $\mathrm{F}(\mathrm{ab})_{2}$ anti-Ig to crosslink BCR but absence of any differentiation agents assessed above, memory B cells showed no appreciable inhibition by ICs, either (Fig. 8b). These findings are consistent with the interpretation of the results above, namely that the FcyRIIB does not act at the level of the activation of memory B cells, which are known to be quiescent, progenitor cell-like and less responsive to mitogenic stimuli [25], but rather inhibits the resulting PCs.

Naïve B cells proliferated over a 5-day period to varying degrees in response to $\mathrm{CpG}$ alone or in combination with SAC plus PWM, IL-2 plus IL-10 or F (ab') $)_{2}$ anti-Ig. Treatment with CpG in combination with SAC and PWM or with $\mathrm{CpG}$ and $\mathrm{F}\left(\mathrm{ab}^{\prime}\right)_{2}$ anti-Ig resulted in the greatest proliferative responses and these were significantly blocked by the AT10 mAb as compared to the isotype matched control mAb (Fig. 8a). Likewise, naïve B cells proliferated in response to $\mathrm{F}(\mathrm{ab})_{2}$ anti-Ig alone but this was inhibited by ICs (Fig. 8b). AT10 had little effect on the naïve B cell proliferative responses to $\mathrm{CpG}$ alone or to $\mathrm{CpG}$ in combination with IL-2 and IL-10. This is likely because CpG mainly promotes differentiation rather than proliferation of human $B$ cells in culture [18]. The selective effect of FcyRIIB crosslinking on the responses of naive $\mathrm{B}$ cells to the different stimuli may reflect differences in either the quality or magnitude of the response. Taken together these results provide evidence that memory $\mathrm{B}$ cell responses are refractory to FcyRIIB regulation in contrast to naïve $B$ cell responses that are sensitive to FcyRIIB inhibition in proliferation.

\section{Discussion}

The FcyRIIB has been shown to serve as a critical peripheral checkpoint to regulate the levels of antibody and results indicate that the Fc $\gamma$ RIIB has the ability to inhibit B-cell responses independently of the BCR. Recent studies have clarified which B-cell subpopulations are susceptible to BCR-independent FcyRIIB regulation in mice. Xiang et al. [13] demonstrated that the FcyRIIB is expressed on long-lived PCs and that these cells undergo apoptosis following FcyRIIB engagement by ICs and Rahman et al. [14] showed that in mice PCs but not germinal center B cells are regulated by the FcyRIIB. These
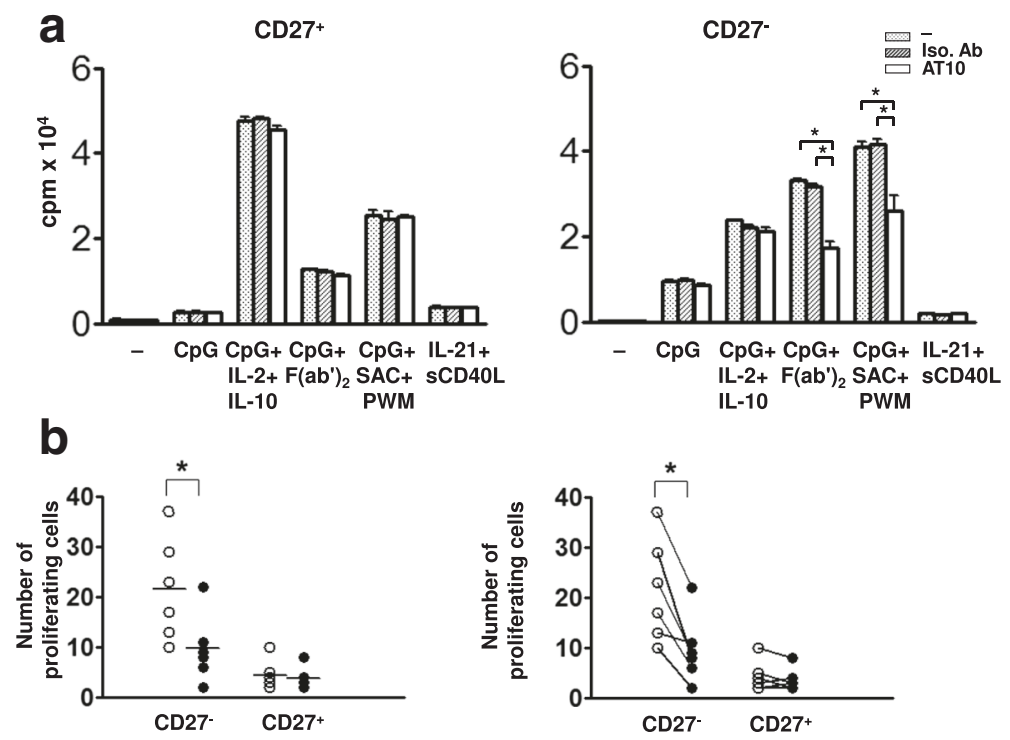

Fig. 8 FcyRIIB inhibits the proliferation of $C D 27^{-}$naive B cells but not $C D 27^{+}$memory B cells. a CD27 ${ }^{+}$and $C D 27^{-}$B cells $\left(10^{6} / \mathrm{ml}\right)$ were cultured for two days before the addition of ${ }^{3}[\mathrm{H}]$ methyl thymidine for another $16 \mathrm{~h}$. Antibodies $(5 \mu \mathrm{g} / \mathrm{ml})$ and stimuli were added to cells in the beginning of culture as in Fig. 6. A representative histogram of more than 3 donors was shown. The asterisks indicate that the differences between the groups compared are statistically significant $(P<0.05)$. Similar results were obtained when cells were cultured for $1-2$ more days before adding ${ }^{3}[\mathrm{H}]$ methyl thymidine. $\mathbf{b} C D 27^{+}$and CD27- B cells $\left(10^{5} / \mathrm{ml}\right)$ from six donors were culture for $48 \mathrm{~h}$ in the presence of $2 \mu \mathrm{g} / \mathrm{ml}$ of $\mathrm{F}(\mathrm{ab})_{2}$ anti-lg $(\operatorname{lgM}+\operatorname{lgG}+\lg A$, Jackson Immunoresesearch) with (open circle) or without (closed circle) $10 \mu \mathrm{g} / \mathrm{ml}$ of ICs. Cells with decreased green fluorescence, indicative of cell division, were counted using flow cytometry and the absolute number $\left(\times 10^{2}\right)$ was plotted as the $Y$-axis. The horizontal bar in each group represents mean of subjects and the asterisks indicate that the differences between the groups compared are statistically significant $(P<0.05)$ 
finding are important as they offer a mechanism by which immunization and the resulting formation of ICs can reduce the number of pre-existing $\mathrm{PCs}$ and thereby create space for new PCs in the limited microenvironments of the bone marrow that support PC survival. Here we show that the Fc $\gamma$ RIIB is expressed on human peripheral blood PCs as well as on naïve and memory B cells and that crosslinking the Fc $\gamma$ RIIB inhibits human ASCs isolated directly from peripheral blood as well as PCs that resulted from the antigen-independent differentiation of human memory B cells. We also demonstrate that the signals transduced by FcyRIIB to exert antigenindependent inhibition require Btk and p38 MAPK. Lastly, we show that both the antigen-independent proliferation and differentiation of naïve B cells in vitro are blocked by FcyRIIB crosslinking. Our studies suggest that the FcyRIIB may play an important role in humans in acutely controlling antibody levels by inhibiting antibody secreting PCs and the activation and proliferation of naïve $\mathrm{B}$ cells. These findings also underscore a crucial mechanism to control B cell homeostasis through the peripheral checkpoints on human PCs and naïve B cells by a negative feedback determined by circulating antibody levels.

Recently it has been shown that polyclonal stimulation through TLRs in the absence of antigen triggers memory $\mathrm{B}$ cells to expand and differentiate into PCs providing a mechanism by which a long-lived PC can be continually replenished throughout an individual's lifetime [17]. However, with the continuous generation of antibodysecreting PCs it is not clear how the levels of antibodies are controlled after reaching sufficient or perhaps even dangerous levels. Our findings that FcyRIIB crosslinking inhibited PCs generated from memory B cells in culture but had no effect on memory B cell proliferation suggests a mechanism by which the FcyRIIB acutely regulate antibody levels without affecting the memory B-cell pool.

Here we also show that although naïve $B$ cells, memory B cells and PCs all express FcyRIIB, they do so at different levels with the lowest expression of Fc $\gamma$ RIIB on naïve B cells and the highest levels on PCs. In general, in immune cells the FcyRIIB is coupled with activating receptors to balance the outcome of responses to complex multiple receptor engagements. Thus, the different levels of the FcyRIIB on naive B cells, memory B cells and PCs may relate to the function of the FcyRIIB in controlling the particular activating receptors expressed in each cell type. The relatively high FcyRIIB expression on PCs may play an important role in triggering apoptosis to achieve homeostatic control. Importantly, we demonstrate that the underlying mechanisms of antigen-independent apoptosis through FcyRIIB depend on Btk and p38 MAPK in the human B cells. Although we previously showed that c-
Abl family kinases are essential for Fc $\gamma$ RIIB-mediated apoptosis in mouse A20 B cells [11], the c-Abl's substrate motif $\left(\underline{Y}^{264} \mathrm{QRP}\right)$ on mouse FcyRIIB appears not conserved in the counterpart of human receptor $\left(\mathrm{Y}^{258} \mathrm{PEC}\right)$. This explains no effect of imatinib, a c-Abl inhibitor, on Fc $\gamma$ RIIB-mediated apoptosis in human B cells (data not shown). Meanwhile, this result raises an interesting question on how and why this divergence occurs during the evolution of adaptive immunity. One additional caveat is that although there is a $\sim 10-15 \%$ less of apoptosis induced by ICs (Fig. 2a) than that of chicken DT40 B cells transfected with the mouse Fc $\gamma$ RIIB for overexpression [11], the magnitude in apoptosis induction of these two cell types is both significant. This is also consistent with the notion that apoptosis mediated by FcyRIIB depends on the signal strength as we previously proposed [11].

Recent studies in mice have underscored the importance of the level of FcyRIIB expression in B cells in the regulation of antibodies levels. Fc $\gamma$ RIIB-deficient mice show an increased accumulation of Ig-secreting cells in the spleen and an enhanced antibody response [12, 24, 26] and eventually die of a lupus-like glomerulonephropathy. Lupus-prone mice often down-regulate the expression of FcyRIIB and the resulting defects can be reversed by increasing FcyRIIB expression levels in B cells [27]. In humans, Mackay et al. [6] showed that peripheral blood $\mathrm{CD} 27^{+}$memory B cells express higher levels of FcyRIIB as compared to naïve B cells but that this level of FcyRIIB is considerably decreased on memory B cells from SLE patients. In addition, Su et al. [5] provided evidence that the expression levels of the FcyRIIB were decreased in memory B cells and PCs in individuals with active SLE as compared to normal controls. The decreased levels of FcyRIIB correlated with decreased levels of FcyRIIB-mediated suppression of BCR-induced calcium responses demonstrating a link between the level of FcyRIIB expression in human B cells and inhibitory activity. Xiang et al. [13] also showed that a multiple myeloma cell line with low FcyRIIB expression levels was resistant to apoptosis and that the susceptibility was restored when FcyRIIB surface expression was increased, indicating a link between the surface expression levels of FcyRIIB and the functional outcomes of crosslinking. We show here that the levels of Fc $\gamma$ RIIB expression on B cells vary as much as six fold between individuals. The factors that influence the expression of FcyRIIB on B cells among healthy donors are largely unknown. It has been reported that IL-4 reduces the expression of FcyRIIB on B lymphocytes and may play a role in Th2 response in mice [28]. It would be of great interest to determine the intrinsic and extrinsic factors that modulate the expression of Fc $\mathrm{R}$ RIB as these may hold the keys to treatment of autoimmune diseases. In light of the findings of Xiang et al. [13] and those 
presented here, selective modulation of FcyRIIB expression on PCs may represent a new therapeutic approach to antibody-mediated autoimmune diseases as previously suggested [29]. One important caveat is that neither $\mathrm{T}$ cells nor NK cells express FcyRIIB and this gives an advantage to modulate humoral immunity through FcyRIIB with little or no impact on the cellular immunity. Lastly, our findings that FcyRIIB functions independently of the BCR to eliminate PCs and inhibit naïve $B$ cell activation while preserve the long-lived memory B cells supports its safe clinical use not only in targeting B cells for the treatment of autoimmune diseases, e.g. SLE, but also in suppressing autoantibodymediated destruction to tissues or cells by intravenous immunoglobulin therapy (IVIg), e.g. immune thrombocytopenic purpura. Under these conditions, administration of either targeting mAbs or polyclonal gamma globulins acutely introduces a high level of antibodies in circulation. Despite the presence of a risk to inadvertently induce antigen-independent inhibition by FcyRIIB, memory B cells can be selectively preserved for replenishment to maintain B cell homeostasis. In addition, patients with systemic lupus erythematosus down-regulate the surface expression of FcyRIIB on memory B cells and PCs, leading to uninhibited expansion of $\mathrm{B}$ cells and autoantibody production $[5,6]$. Our data strongly support a crucial role of FcyRIIB to function in the elimination of autoreactive B cells to prevent from antibody-mediated autoimmune diseases and further underscore the importance of antigen-independent inhibition by Fc $\gamma$ RIIB as a peripheral checkpoint in human B cells. Namely, lower expression of FcyRIIB not only allows autoreactive PCs to break tolerance but also lowers the threshold for them to activate and expand, thereby allowing secretion and accumulation of more autoantibodies to form ICs that can deposit in tissues, e.g. the kidney, to cause damage and inflammation. It is then conceivable that restoration of the expression level of FcyRIIB on B cells may be beneficial for patients with SLE to alleviate lupus nephritis in that circulating ICs can then self-eliminate autoreactive PCs through apoptosis. Indeed, partial restoration of the expression level of $\sim 40 \%$ of FcyRIIB on B cells by retroviral transfection is sufficient to restore tolerance and ameliorate disease activity in lupus mice [30]. Since PCs are most sensitive to apoptosis triggered by FcyRIIB (Fig. 7) [13, 14] targeting Fc $\gamma$ RIIB likely will affect PCs effectively, including those resident in the bone marrow.

\section{Conclusion}

These results provide evidence that human peripheral blood PCs and naïve B cells but not memory B cells are main targets of FcyRIIB's antigen-independent regulation. This observation suggests a mechanism by which antibody levels can be acutely regulated by ICs during antibody responses while maintaining B cell homeostasis. Moreover, our findings indicate that the graded expression levels of FcyRIIB in B cell subpopulations (PCs $>$ memory cells $>$ naïve cells) dictate the outcomes of FcyRIIB-mediated inhibition independent of BCR and provide new insights into safe use of antibody targeted therapy in autoimmune diseases, e.g. SLE. More importantly, we demonstrate for the first time that antigenindependent inhibition by FcyRIIB is mediated by Btk and p38 MAPK in human B cells. These findings in humans also extend our previous work on mouse B cells and further underscore the importance of antigenindependent Fc $\gamma$ RIIB regulation of antibody responses in humans since a failure of FcyRIIB to mediate apoptosis of PCs might result in susceptibility to systemic lupus erythematosus [5, 6]. Taken together, FcyRIIB may be considered as a new drug target for selective modulation in the treatment of antibody-mediated autoimmune diseases.

\section{Abbreviations}

ASCs: Antibody-secreting cells; BCR: B-cell receptor; ICs: Immune complexes; IL: Interleukin; mAb: Monoclonal antibody; PAP: Peroxidase-anti-peroxidase; PCs: Plasma cells; PWM: Pokeweed mitogen; sCD40L: Soluble CD40 ligand; SAC: Staphylococcus aureus Cowan; SLE: Systemic lupus erythematosus; Th2: T helper type 2; TLR: Toll-like receptor.

\section{Competing interests}

The authors declare that they have no competing interests.

\section{Authors' contributions}

ST participated in the design of study, performed the experiments and wrote the manuscript. WL and HW performed experiments, analyzed data and prepared figures. All authors read and approved the final manuscript.

\section{Acknowledgements}

This study was supported by research grants from the Ministry of Science and Technology of the Executive Yuan of Taiwan (NSC98-2320-B-002-056 and NSC99-2320-B-002-011). We thank Dr. Ming-Yi Wu of the Department of Obstetrics and Gynecology and Dr. Tur-Fu Huang in the Graduate Institute of Pharmacology of National Taiwan University for helping recruitment of blood donors. I would like to greatly thank Dr. Wenyu Hsiao and Ms Ho-Yin Huang for their excellent technical supports. We would like to acknowledge the service provided by the Flow Cytometric Analyzing and Sorting core of the first Core Laboratory, College of Medicine, National Taiwan University.

Received: 25 August 2015 Accepted: 6 October 2015

Published online: 16 October 2015

\section{References}

1. Nimmerjahn F, Ravetch JV. FcyRs in health and disease. Curr Top Microbiol Immunol. 2011;350:105-25.

2. Daeron M. Fc receptors as adaptive immunoreceptors. Curr Top Microbiol Immunol. 2014:382:131-64.

3. Kono H, Kyogoku C, Suzuki T, Tsuchiya N, Honda H, Yamamoto K, et al. FcyRIIB Ile232Thr transmembrane polymorphism associated with human systemic lupus erythematosus decreases affinity to lipid rafts and attenuates inhibitory effects on B cell receptor signaling. Hum Mol Genet. 2005;14:2881-92.

4. Floto RA, Clatworthy MR, Heilbronn KR, Rosner DR, MacAry PA, Rankin A, et al. Loss of function of a lupus-associated FcyRllb polymorphism through exclusion from lipid rafts. Nat Med. 2005;11:1056-8.

5. Su K, Yang H, Li X, Li X, Gibson AW, Cafardi JM, et al. Expression profile of FcyRllb on leukocytes and its dysregulation in systemic lupus erythematosus. J Immunol. 2007;178:3272-80. 
6. Mackay M, Stanevsky A, Wang T, Aranow C, Li M, Koenig S, et al. Selective dysregulation of the FcyllB receptor on memory B cells in SLE. J Exp Med. 2006;203:2157-64.

7. Ono M, Bolland S, Tempst P, Ravetch JV. Role of the inositol phosphatase SHIP in negative regulation of the immune system by the receptor FcyRIIB. Nature. 1996;383:263-6.

8. Chacko GW, Tridandapani S, Damen JE, Liu L, Krystal G, Coggeshall K. Negative signaling in B lymphocytes induces tyrosine phosphorylation of the $145-\mathrm{kDa}$ inositol polyphosphate 5-phosphatase, SHIP. J Immunol. 1996;157:2234-8.

9. Sarmay G, Koncz G, Pecht I, Gergely J. Fcy receptor type Ilb induced recruitment of inositol and protein phosphatases to the signal transductory complex of human B-cell. Immunol Lett. 1997;57:159-64.

10. Pearse RN, Kawabe T, Bolland S, Guinamard R, Kurosaki T, Ravetch JV. SHIP recruitment attenuates FcyRIIB-induced B cell apoptosis. Immunity. 1999;10:753-60.

11. Tzeng SJ, Bolland S, Inabe K, Kurosaki T, Pierce SK. The B cell inhibitory Fc receptor triggers apoptosis by a novel c-Abl family kinase-dependent pathway. J Biol Chem. 2005;280:35247-54.

12. Fukuyama $\mathrm{H}$, Nimmerjahn F, Ravetch JV. The inhibitory Fcy receptor modulates autoimmunity by limiting the accumulation of immunoglobulin G+ anti-DNA plasma cells. Nat Immunol. 2005;6:99-106.

13. Xiang Z, Cutler AJ, Brownlie RJ, Fairfax K, Lawlor KE, Severinson E, et al. FcyRllb controls bone marrow plasma cell persistence and apoptosis. $\mathrm{Na}$ Immunol. 2007:8:419-29.

14. Rahman ZSM, Alabyev B, Manser T. FcyRIIB regulates autoreactive primary antibody-forming cell, but not germinal center B cell activity. J Immunol. 2007;178:897-907.

15. Fournier EM, Sibéril S, Costes A, Varin A, Fridman WH, Teillaud JL, et al. Activation of human peripheral lgM+B cells is transiently inhibited by BCR-independent aggregation of FcyllB. J Immunol. 2008;181:5350-9.

16. Jahnmatz M, Kesa G, Netterlid E, Buisman AM, Thorstensson R, Ahlborg N. Optimization of a human IgG B-cell ELISpot assay for the analysis of vaccine-induced B-cell responses. J Immunol Methods. 2013;121:392-404.

17. Bernasconi NL, Traggiai E, Lanzavecchia A. Maintenance of serological memory by polyclonal activation of human memory B cells. Science. 2002;298:2199-202.

18. Bernasconi NL, Onai N, Lanzavecchia A. A role for Toll-like receptors in acquired immunity: up-regulation of TLR9 by BCR triggering in naive $B$ cells and constitutive expression in memory B cells. Blood. 2003;101:4500-4.

19. Jiang W, Ledeman MM, Harding CV, Rodriquez B, Mohner RJ, Sieg SF. TLR9 stimulation drives naïve $B$ cells to proliferate and to attain enhanced antigen presenting function. Eur J Immunol. 2007;37:2205-13.

20. He B, Qiao X, Cerutti A. CpG DNA induces IgG class switch DNA recombination by activating human $B$ cells through an innate pathway that requires TLR9 and cooperates with IL-10. J Immunol. 2004;173:4479-91.

21. Crotty S, Aubert RD, Glidewell J, Ahmed R. Tracking human antigen-specific memory B cells: a sensitive and generalized ELISPOT system. J Immunol Methods. 2004;286:111-22.

22. Ettinger $R$, Sims GP, Fairhurst AM, Robbins $R$, da Silva YS, Spolski R, et al. $\mid L-21$ induces differentiation of human naive and memory $B$ cells into antibody-secreting plasma cells. J Immunol. 2005;175:7867-79.

23. Maizel AL, Morgan JW, Mehta SR, Kouttab NM, Bator JM, Sahasrabuddhe CG. Long-term growth of human B cells and their use in a microassay for B-cell growth factor. Proc Natl Acad Sci U S A. 1983;80:5047-51.

24. Huggins J, Pellegrin T, Felgar RE, Wei C, Brown M, Zheng B, et al. CpG DNA activation and plasma-cell differentiation of $C D 27^{-}$naive human $B$ cells. Blood. 2007;109:1611-9.

25. Fearon DT, Manders $P$, Wagner SD. Arrested differentiation, the self-renewing memory lymphocyte, and vaccination. Science. 2001;293:248-50.

26. Papadimitraki ED, Choulaki C, Koutala E, Bertsias G, Tsatsanis C, Gergianaki I, et al. Expansion of toll-like receptor 9-expressing B cells in active systemic lupus erythematosus: implications for the induction and maintenance of the autoimmune process. Arthritis Rheum. 2006;54:3601-11.

27. Takai T, Ono M, Hikida M, Ohmori H, Ravetch JV. Augmented humoral and anaphylactic responses in FcyRll-deficient mice. Nature. 1996;379:346-9.

28. Rudge EU, Cutler AJ, Pritchard NR, Smith KGC. Interleukin 4 reduces expression of inhibitory receptors on B cells and abolishes CD22 and FcyRII-mediated B cell suppression. J Exp Med. 2002;195:1079-85.

29. Li X, Kimberly RP. Targeting the Fc receptor in autoimmune disease. Expert Opin Ther Targets. 2014;18:335-50.

30. McGaha TL, Sorrentino B, Ravetch JV. Restoration of tolerance in lupus by targeted inhibitory receptor expression. Science. 2005;307:590-3.

\section{Submit your next manuscript to BioMed Central and take full advantage of:}

- Convenient online submission

- Thorough peer review

- No space constraints or color figure charges

- Immediate publication on acceptance

- Inclusion in PubMed, CAS, Scopus and Google Scholar

- Research which is freely available for redistribution

Submit your manuscript at www.biomedcentral.com/submit 